\title{
Diversity of West African dwarf goat in southwestern Nigeria based on allozyme
} markers

*awobajo, O. K., ${ }^{\mathrm{b}}$ Osaiyuwu, O. H., ${ }^{\mathrm{b}}$ Akinyemi, M. O., ${ }^{\mathrm{b}}$ Salako, A. E. and ${ }^{\mathrm{a}}$ Odeniyi, A. O. ${ }^{a}$ Department of Agricultural Science Education, Tai Solarin University of Education P. M. B. 2118, Ijebu-Ode, Ogun State, Nigeria.

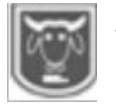

${ }^{b}$ Animal Breeding and Genetics Laboratory, Department of Animal Science, University of Ibadan Ibadan, Nigeria

Abstract *Corresponding author: koyakola@gmail.com

Effective conservation, rational management and inadequate information on genetic diversity are the major challenges in livestock production. Genetic diversity has been used to reveal the extent of differentiation within livestock species. However, information on the use of allozymes in genetic diversity of the West African Dwarf (WAD) goat is insufficient. Therefore, genetic diversity of the WAD goat populations in southwestern Nigeria was investigated in this study. Three protein loci markers were used. Blood (5 $\mathrm{mL}$ each) samples were randomly collected from 20, 20, 40 and 60 goats from Ondo, Oyo, Ogun and Osun States respectively. The samples were subjected to cellulose acetate electrophoresis to determine the genetic variants at Haemoglobin (Hb), Carbonic Anhydrase (CA) and Transferrin (Tf) loci. Another set of blood $(5 \mathrm{~mL})$ from 20 different individual animals were randomly obtained from each of Ondo, Oyo, Ogun, and Osun States. Allele frequency, observed heterozygosity $\left(H_{O}\right)$, Polymorphic Information Content $(P I C), F$-statistic $\left(F_{S T,} F_{I T}\right.$ and $\left.F_{I S}\right)$, gene flow $(\mathrm{Nm})$, gene diversity $(D)$, number of alleles per loci $\left(A_{p}\right)$, effective number of allele $\left(A_{E}\right)$, Mean Number of Allele (MNA) were generated from the data obtained. Data were analysed using Hardy-Weinberg equilibrium (HWE) at $\alpha_{0.05}$. The allele frequency ranged between $0.11\left(\mathrm{Hb}^{\mathrm{A+}}\right)$ and $0.58\left(\mathrm{Hb}^{B^{+}}\right), 0.17\left(\mathrm{CA}^{F+}\right)$ and $0.44\left(\mathrm{CA}^{F S}\right)$ and $0.08\left(T f^{\mathrm{A+}}\right)$ to 0.60 $\left(T f^{A B}\right)$. Deviation from HWE was not significant in all populations except at Tf locus $(0.00)$. The $H_{O}$ ranged from 0.43 to 0.62 and Nm and $D$ ranged between 3.68 and 32.40 and 0.34 to 0.50 respectively. The MNA was 0.67 but $A_{E}$ ranged from 1.52 to 2.00. The allozymes revealed some level of genetic diversity and a genetic differentiation indicative of the amount of genetic differences among individuals within the West African Dwarf goat population.

Keywords: Goat polymorphism, allozyme markers, genetic and biochemical characterisation, genetic variability

\section{Introduction}

Genetic improvement of indigenous breeds of livestock is very valuable because of high adaptability to harsh environmental conditions of nutrition, climate and disease compared with exotic breeds (Fitzhugh et al., 1992). According to Groeneveld et al.(2010) many breeds of livestock may become lost germplasmin many third world countries due to crossingwith exotics, which in addition to uncontrolled breeding in extensive management systems pose a great risk forthe loss of valuable genes. The mean number of alleles (MNA), observed $\left(H_{O}\right)$ and expected $\left(H_{E}\right)$ heterozygosity are the most commonly calculated population genetic parameters for assessing within breed diversity (Hanotte and Jianlin, 2005). The time of goat domestication was before $7000 \mathrm{BC}$ around the boarders of the present day Iran and Iraq, (Mason, 1984). Domestic goats with scimitar-like horn are considered to have descended from Bezoar goat (Capra hircus aegargus) in South Asia, where the wild form still exists. However, 


\section{Diversity of West African dwarf goat in southwestern Nigeria based on allozyme markers}

the short-eared and short-horned goat maintained their presence in the equatorial West, Central and East Africa. In humid and hot climate of West and Central Africa, the present day goats of this type tend to be dwarf, which is believed to be due to natural selection on thermoregulation under the unfavourable humid and hot climate. In addition the West African Dwarf (WAD) goat often has short bowed legs attributed to achondroplasia (Wilson, 1991). The distribution of this goat type extends southwards through Central Africa as far as Zaire, Angola and the north of Namibia (Mason, 1984). WAD goat probably evolved specially in response to the conditions of the humid forest zone by selection of recessive genes for dwarfism (Wilson, 1991). The true type of this goat is considered to be confined to fifteen countries in West and Central Africa, all of which except the Central African Republic have an Atlantic coastline (Guinea Bissau, Guinea, Liberia, Sierra Leone, Cote d'Ivoire, Ghana, Togo, Benin, Nigeria, Cameroon, Congo, Equatorial Guinea, Gabon, Zaire, and Central African Republic). It is also found in Senegal (Wilson, 1991). The ability of goats to tolerate harsh climates, the presence of trypanotolerance in some breeds (Salako, 2004), suitability to traditional systems on account of small size, short generation interval (Abdul-Aziz, 2010) and ability to thrive on poor quality diets provided by scarce grazing on marginal lands (Adedeji et al., 2011) all combine to make WAD goat strategic to increasing livestock productivity in rural agricultural systems (Adebambo et al., 2004; Adedeji et al., 2011). Despite these advantages, little attention had been paid to the genetic characterization and possible improvement of small ruminants in Nigeria. Several reports on performance characteristics have been published by Odubote and
Akinokun (1992); Odubote (1994a, b); Ebozoje and Ngere (1995); Ozoje (1998) and Imumorin et al. (1999). There are three main breeds of goat in Nigeria, the West African Dwarf, the Sokoto Red and the Sahel. Goats are renowned for their hardiness and can survive in most environments: West African Dwarf goats are kept in the forest zones and in the Middle belt; Sokoto Red are kept throughout the north; and Sahelgoats are restricted to a strip along the frontier with the Republicof Niger (Bourn et al., 1994). The future development of livestock production in sub-Saharan Africa is hindered by limited knowledge of the genetic potential of the local genetic resources and ways to best utilize these resources in a sustainable manner. Traditional methods used to study genetic variability of animals and populations employed polymorphism in protein markers and genetic variation of haemoglobin (Buvanendran et al., 1981; Imumori et al., 1999) and transferrin types in goats (Moruppa, 1985; Kitalyi, 1998; Yakubu et al., 2010a, b; Mourad et al., 2001). Although DNA-based technologies are now the methods of choice for genetic characterization of livestock (Arora et al., 2011), several alternative assays, such as protein/ allozyme polymorphisms, remain tremendously useful, especially in developing countries, because of their utility, ease, cost and amount of genetic information accessed or simplicity of data interpretation (Rege and Okeyo, 2006). Mwacharo et al. (2002) reported that for populations whose genetic status is unknown, protein polymorphism may be used first to verify the degree of genetic relationship and to prioritize breeds to be analysed using microsatellites. There is dearth of information on the genetic variability of Nigerian breeds of WAD goat based on blood protein polymorphism 


\section{Awobajo, Osaiyuwu, Akinyemi, Salako and Odeniyi}

especially the extent of natural genetic variation in WAD goats in Nigeria. Therefore, the present study aimed at using allozyme analysis in investigating and estimating genetic diversity among different populations of WAD goat breeds in Southwestern Nigeria. The results of this study will provide useful genetic information essential for developing more effective extensive molecular characterization of WAD goat in Nigeria and understand the genetic diversity of WAD goat to implement steps so as to ensure their conservation and rational utilization for improvement of this genetic resources and productivity for the benefit of the farmers.

\section{Materials and methods \\ Experimental procedure}

One hundred and forty animals, twenty from each sampling area comprising IjebuOde and Ado - Odo, (Ogun state), Ondo, (Ondo state), Ile -Ife, Osogbo and Iwo, (Osun state), and Ibadan, (Oyo state), were randomly selected. Blood was collected from each animal by jugular venipuncture and placed in heparinized tubes to prevent coagulation. Red blood cell was harvested from the blood blood by centrifuging at 2500-3000 rpm for $10 \mathrm{mins}$ at $4{ }^{\circ} \mathrm{C}$. The Red Blood Cell (RBC) was washed in saline $(0.155 \mathrm{M} \mathrm{NaCl})$ three times and centrifuged at 2500-3000 rpm for 5 mins at $4{ }^{\circ} \mathrm{C}$. The RBCs were lysed with a fourthfold volume of distilled $\mathrm{H}_{2} \mathrm{O}$ to release heamoglobin according to RIKEN (2006). The plasma fraction is separated from the erythrocyte fraction of haparinized blood by centrifuging at 2500$3000 \mathrm{rpm}$. Cellulose Acetate Electrophoresis was performed according to RIKEN (2006). Band scoring was carried out to visualize the protein bands.

\section{Statistical analysis}

Tools for Population Genetic Analyses (TFPGA) (Miller, 1997) software was used to generate the genetic distance according to Nei (1972), the allele frequency, observed and expected heterozygosity, Hardy-Weinberg Equilibrium, the inbreeding coefficients i.e Wright's $\mathrm{F}_{\text {IS }}$ and $\mathrm{F}_{\mathrm{IT}}, \mathrm{F}_{\mathrm{ST}}$ estimates, from the data obtained from the laboratory analysis and drawing UnPaired Group Method of Algorithm (UPGMA) dendrograms was alsao done.

\section{Results and discussions}

Proteins markers used in this study were similar to Rout et al. (2008) for diversity in Indian goats. From Table 1, all loci studied were polymorphic as indicated by the Shannon information index (SII) $>0.50$, which make them useful in genetic diversity studies. The Shannon information index ranged between 0.53 to 0.69 with an overall mean of $0.63 \pm 0.09$. The total numbers of alleles per locus (2) and high SII values suggested that these markers are informative for genetic diversity in WAD goats sampled and that Nigerian goats possess a wide genetic base that allows for adaptation to a wide variety of ecological environments. Allelic richness of 2 in this study, is lower than 8.1-9.7 obtained from microsatellite analysis of Indian goats by (Rout et al., 2008), average of 7.3 in Iranian goats (Mahmoudi et al., 2010), averageof 5.9 in Canary Island goats (Martínez et al., 2006), and also lower than the Spanish Guadarrama goats with 9-36 (Serrano et al., 2009) and Nigeria goats with 8-26 (Okpeku et al., 2011). This may be due to higher level of polymorphism in microsatellite than in protein markers. However it falls within the range 2-7 obtained for Nigerian sheep using the same protein maker (Akinyemi and Salako 2012). Salako et al. (2007) reported same value for haemoglobin in WAD goat while higher value (3) was reported by Jaayid 2012 for transferrin in Iraqi goat. Gene diversity of 0.34 in $\mathrm{Hb}$ and 0.50 in $\mathrm{Tf}$, were lower than 0.54 and 0.51 reported by 


\section{Diversity of West African dwarf goat in southwestern Nigeria based on allozyme markers}

Muema et al. (2009) and Adebambo et al. (2011) in Nigerian goats for microsatellite loci. However this value was higher than 0.44 and 0.38 reported by Salako et al. (2007) and Akinyemi and Salako (2012) in Nigerian WAD goat and sheep. This higher value indicated an increasing genetic variability in Nigerian WAD goat. However, all the loci except transferrin locus had $\mathrm{H}_{\mathrm{O}}$ lower than their expectedvalues indicating departure from random mating which suggest that they are homozygous in these populations and may indicate on-going selection or may be linked to other loci affecting morphological, productive or adaptive traits under going selection (Dixit et al., 2008; Bruno-de-Sousa et al., 2011) or result from mating between relatives and consequent genetic drift, similar to what has been observed in many other goat populations (Agha et al., 2008; Rout et al., 2008; Dixit et al., 2009).

\section{Measures of genetic variability}

Table 2 Showed that the average $\mathrm{H}_{\mathrm{O}}$ ranged from 0.43 in sample from Ondo to 0.62 in sample from Ogun.The mean $H_{E}$, an indication of gene diversity ranged from 0.39 in the sample from Osun to 0.48 in sample from Ogun, indicating that the sample from Osun showed the lowest gene diversity, while the sample from Ogun showed the highest gene diversity among WAD goats populations. The mean numbers of alleles per locus (MNA) remained constant (0.67) for the entire populations. Also the Total Number of Alleles (TNA) was constant for all the populations. Deviations from HardyWeinberg's Equilibrium (HWE) were statistically significant $(\mathrm{P}<0.05)$ in 1 locus in Oyo and Osun state and 3 loci in both Ogun and Ondo state. The mean number of alleles observed over a range of loci in different populations in Table 2 was considered to be a reasonable indicator of genetic variation within the populations (Cavalli-Sforza 1998). When compared to 7.77 from the Kalahan Red goat breed from South Africa (Kotze et al., 2004), the WAD goat showed lower mean number allele of 0.67 in all sample population. This was lower than what was reported by Ganai and Yadav (2001) in three Indian goat breeds using heterologous microsatellite markers Sirohi (4.12), Jamnapari (4.00) and Barbari (3.37). Generally, the mean number of alleles is highly dependent on the sample size because the number of observed alleles tends to increase depending on the population size.Heterozygotes values obtained with microsatellite markers are generally higher (due to higher levels of polymorphism) than those obtained with protein markers. In comparison studies between protein markers and microsatellites, have brought out the advantages of the latter, Arranz et al., (1996).

\section{Observed and expected Heterozygosity}

Also from Table 2 the $\mathrm{H}_{\mathrm{O}}$ is generally higher than the $\mathrm{H}_{\mathrm{E}}$ for all populations sampled except for sample from Ondo, indicating departure from random mating which suggested that the populations were homozygous in nature and may also indicate on-going selection or may be linked to other loci affecting morphological, productive or adaptive traits undergoing selection (Dixit et al., 2008; Bruno-de-Sousaet al., 2011) or may have resulted from mating between relative and consequent genetic drift, similar to what has been observed in many other goat populations (Agha et al., 2008; Rout et al., 2008; Dixit et al., 2009). A more appropriate measure of genetic variation within a population was gene diversity (average expected heterozygosity) (Nei, 1987) and it ranged from 0.39 in population from Osun to 0.48 in population from Ogun. These value falls within the recommended 


\section{Awobajo, Osaiyuwu, Akinyemi, Salako and Odeniyi}

average heterozygosity of 0.3 and 0.8 (Takezaki and Nei, 1996). According to them, markers are considered useful for measuring genetic variation, when they have an average heterozygosity ranging from 0.3 to 0.8 in the populations. This again confirmed that these markers were appropriate for measuring genetic variation. $\mathrm{H}_{\mathrm{E}}$ value reported in this study (0.39-0.48) is lower than 0.51 reported by Adebambo et al. (2011) in Nigerian goats, 0.72 for Egyptian goats (Agha et al., 2008), 0.63-0.69 in South African goats (Visser et $a l ., 2004)$ and $0.60-0.92$ reported by Okpeku et al., 2011 though they are all from microsatellite loci which are highly polymorphic. These values were higher than 0.44 reported by Salako et al., 2007 for protein locus.

\section{Deviation from Hardy-Weinberg's} equilibrium

Also from table 2, deviation from Hardy-
Weinberg's Equilibrium which was very highly significant $(\mathrm{P}<0.001)$ in three populations (Ogun, Ondo, and Osun state) and was highly significant $(\mathrm{P}<0.01)$ in sample from Oyo state was a confirmation of departure from random mating which suggest that the populations were homozygous in nature as revealed by the measure of heterozygosities and may also indicate on-going selection or may be linked to other loci affecting morphological, productive or adaptive traits undergoing selection (Dixit et al., 2008; Bruno-de-Sousa et al., 2011). These result also implied that the populations must have been subjected to certain level of inbreeding as a result of some form of selection within the various sampled populations, (Dixit et al., 2008; Bruno-deSousa et al., 2011).

Table 1: Measures of genetic variation at studied blood protein loci in West African dwarf goat

\begin{tabular}{|c|c|c|c|c|c|c|c|c|c|}
\hline SN & Loci & $\begin{array}{l}\text { Sample } \\
\text { size }\end{array}$ & $\begin{array}{l}\text { Observed } \\
\text { no of } \\
\text { alleles }\end{array}$ & $\begin{array}{l}\text { Effective } \\
\text { number of } \\
\text { alleles }\end{array}$ & $\begin{array}{l}\text { Shannon's } \\
\text { information } \\
\text { index }\end{array}$ & $\begin{array}{l}\text { Heterozy } \\
\text { Observed }\end{array}$ & $\begin{array}{l}\text { osity } \\
\text { Expected s }\end{array}$ & Nei's & $\begin{array}{l}\text { Heterozygote } \\
\text { deficiency }\end{array}$ \\
\hline 1 & $\mathrm{Hb}$ & 123 & 246 & 1.52 & 0.53 & 0.34 & 0.34 & 0.34 & 0.28 \\
\hline 2 & CA & 123 & 246 & 1.94 & 0.68 & 0.46 & 0.49 & 0.48 & -0.70 \\
\hline 3 & $\mathrm{Tf}$ & 125 & 250 & 2.00 & 0.69 & 0.84 & 0.50 & 0.50 & -0.13 \\
\hline Mean & & 123.67 & 247.33 & 1.82 & 0.63 & 0.55 & 0.44 & 0.44 & -0.18 \\
\hline St. Dev & & & 0.00 & 0.26 & 0.09 & 0.26 & 0.09 & 0.09 & 0.50 \\
\hline
\end{tabular}

Table 2: Total number of alleles, mean number of alleles, observed and expected heterozygosity and deviation from Hardy-Weinberg's equilibrium in different population of WAD goat

\begin{tabular}{|c|c|c|c|c|c|c|}
\hline Population & $\begin{array}{l}\text { Sample } \\
\text { size }\end{array}$ & $\begin{array}{l}\text { Total number } \\
\text { of alleles } \\
\text { (TNA) }\end{array}$ & $\begin{array}{l}\text { Alleles/locus } \\
\text { (MNA) }\end{array}$ & $\begin{array}{l}\text { Heterozygosity } \\
(\text { Observed })\left(\mathrm{H}_{\mathrm{O}}\right)\end{array}$ & $\begin{array}{l}\text { Heterozygosity } \\
\text { (Expected) }\left(\mathrm{H}_{\mathrm{E}}\right)\end{array}$ & DHWE \\
\hline Ogun & 40 & 2 & 0.67 & 0.62 & 0.48 & $3 * * *$ \\
\hline Ondo & 10 & 2 & 0.67 & 0.43 & 0.47 & $3 * * *$ \\
\hline Osun & 53 & 2 & 0.67 & 0.52 & 0.39 & $1 * * *$ \\
\hline Oyo & 20 & 2 & 0.67 & 0.55 & 0.46 & $1 * *$ \\
\hline
\end{tabular}

The mean number of alleles per locus (NA), Total Number of Alleles (TNA), Mean Number of Alleles (MNA), Deviation from HardyWeinberg's Equilibrium (DHWE)

\section{F-Statistic}

From Table 3 observed $\mathrm{F}_{\mathrm{IT}}$ values ranged from -0.66 for $\mathrm{Tf}$ to 0.18 for $\mathrm{Hb}$. Increasing $\mathrm{F}_{\mathrm{IT}}$ values suggested some measure of homozygosity and heterozygote deficit resulting from relatedness of individuals which may be as a result of inbreeding within the populations of WAD goat. $\mathrm{F}_{\mathrm{IS}}$ 


\section{Diversity of West African dwarf goat in southwestern Nigeria based on allozyme markers}

values ranged from $-0.67(\mathrm{Tf})$ to $0.13(\mathrm{Hb})$ with a mean of -0.21 . Negative $F_{\text {IS }}$ suggest that the populations are outbred (has an excess of heterozygotes), though the value is positive for two ( $\mathrm{Hb}$ and $\mathrm{CA}$ ) loci suggesting that the population is deficient in heterozygote (an in bred populations) at those loci while negative $\mathrm{F}_{\mathrm{IS}}$ at $\mathrm{Tf}$ locus suggested excess heterozygote which have also been reported in other studies on goats (Barker et al., 1997; Luikart et al., 1999; Agha et al., 2008; Rout et al., 2008; Dixit et al., 2009). Heterozygote deficiencies may be due to factors like, population subdivision owing to genetic drift, null alleles and selection against heterozygotes or inbreeding (Hoarau et al., 2005). Although locus $\mathrm{Hb}$ showed the highest $\mathrm{F}_{\text {Is }}$ values indicating fixation at this locus, distinguishing among these factors is generally difficult according to Christiansen et al. (1974). The $\mathrm{F}_{\mathrm{ST}}$ values ranged from 0.01 for $\mathrm{Tf}$ to 0.06 for $\mathrm{Hb}$. Low
$\mathrm{F}_{\mathrm{ST}}$ indicates some measure of gene flow between the sampled populations, with $\mathrm{Hb}$ locus recording the highest gene flow of 0.06. Mujibi (2005) reported a low $\mathrm{F}_{\mathrm{ST}}$ of $5.8 \%$ for WAD goats in Kenya; therefore, gene flow estimates in this study suggested mobility and considerable exchange of genetic material among these WAD goats' populations. These could be attributed to the fact that most of these animals are reared under extensive system of management allowing the animals to roam freely and fend for themselves in most rural households and communities and also as a result of interstate movement of these animals by man. This enables and reinforces the ability of related animals to meet on pasture to breed or for neighbours to exchange related animals for up keep or breeding. According to Laval et al. (2000), migration may exert a greater effect than mutation or drift on the reduction in genetic differentiation between populations.

Table 3: Wright's F-statistics analyses for 3 protein loci in WAD goats

\begin{tabular}{lllll}
\hline Locus & $F\left(F_{\text {IS }}\right)$ & $\Theta\left(F_{\text {ST }}\right)$ & $F\left(F_{\text {IT }}\right)$ & $\mathrm{Nm}^{*}$ \\
\hline $\mathrm{Hb}$ & 0.13 & 0.06 & 0.18 & 3.68 \\
$\mathrm{CA}$ & $0.05^{*}$ & $0.03^{*}$ & 0.08 & 8.15 \\
$\mathrm{Tf}$ & -0.67 & $0.01^{* *}$ & -0.66 & 32.40 \\
Mean & -0.21 & $0.03^{*}$ & -0.17 & 14.74 \\
\hline
\end{tabular}

$*_{\mathrm{Nm}}=$ Gene flow estimated from Fst = 0.25(1 $\quad$ - Fst)/Fst.Hb -.-->>Haemoglobin, CA-->Carbonic anhydrase, $\quad$ Tf -..$>$ Transferrin.

\section{Number of alleles}

Table 4 revealed total numbers of alleles per locus across all populations was 2 and this allelic richness (2) was lower than observed 8.1-9.7 in Indian goats (Rout et al., 2008), average of 7.3 in Iranian goats (Mahmoudi et al., 2010), and average of 5.9 in Canary Island goats (Martínez et al., 2006), 9-36 in Spanish Guadarrama goats (Serrano et al.,
2009) and 8-26 in Nigeria goats (Okpeku et al., 2011), but similar to what was reported by Salako et al. (2007). A total of 6 alleles were observed in the investigated loci. All loci sampled were polymorphic. Equal numbers of alleles were observed in all the investigated loci and the highest number of alleles ( 2 alleles) occurred in all the loci and across all populations. 


\section{Awobajo, Osaiyuwu, Akinyemi, Salako and Odeniyi}

Table 4: Allele frequencies at thehaemoglobin, carbonic anhydrase and transferrine loci of WAD goat population from Ogun, Ondo, Osun and Oyo state

\begin{tabular}{lllllll}
\hline Locus & Allele & Ogun & Ondo & Osun & Oyo & Average \pm SD \\
\hline $\mathrm{Hb}$ & $\mathrm{Hb}^{\mathrm{A}}$ & 0.33 & 0.40 & 0.10 & 0.23 & $0.26 \pm 0.13$ \\
& $\mathrm{Hb}^{\mathrm{B}}$ & 0.68 & 0.60 & 0.90 & 0.78 & $0.74 \pm 0.11$ \\
$\mathrm{CA}$ & $\mathrm{CA}^{\mathrm{F}}$ & 0.43 & 0.25 & 0.41 & 0.48 & $0.39 \pm 0.10$ \\
& $\mathrm{CA}^{\mathrm{S}}$ & 0.58 & 0.75 & 0.59 & 0.53 & $0.61 \pm 0.10$ \\
$\mathrm{Tf}$ & $\mathrm{Tf}^{\mathrm{A}}$ & 0.50 & 0.50 & 0.45 & 0.58 & $0.51 \pm 0.05$ \\
& $\mathrm{Tf}^{\mathrm{B}}$ & 0.50 & 0.50 & 0.55 & 0.43 & $0.49 \pm 0.05$ \\
\hline
\end{tabular}

Hb ----->Haemoglobin, CA ---->Carbonic anhydrase， Tf -.-->Transferrin.

Table 5 : Genotype frequencies of WAD goat population from Ogun, Ondo, Osun and Oyo state at haemoglobin, carbonic anhyrase and transferrin loci

\begin{tabular}{llllll}
\hline & Ogun & Ondo & Osun & Oyo & Average \pm SD \\
\hline Haemoglobin & & & & & \\
$\mathrm{Hb}^{\mathrm{A+}}$ & $\mathrm{NA}$ & 0.30 & 0.02 & 0.10 & $0.11 \pm 0.14$ \\
$\mathrm{Hb}^{\mathrm{AB}}$ & 0.65 & 0.20 & 0.17 & 0.25 & $0.32 \pm 0.22$ \\
$\mathrm{Hb}^{\mathrm{B}+}$ & 0.35 & 0.50 & 0.81 & 0.65 & $0.58 \pm 0.20$ \\
Carbonic anhydrase & & & & & \\
$\mathrm{CA}^{\mathrm{F}+}$ & 0.28 & 0.20 & 0.15 & 0.05 & $0.17 \pm 0.09$ \\
$\mathrm{CA}^{\mathrm{FS}}$ & 0.30 & 0.10 & 0.51 & 0.85 & $0.44 \pm 0.32$ \\
$\mathrm{CA}^{\mathrm{S}+}$ & 0.43 & 0.70 & 0.34 & 0.10 & $0.39 \pm 0.25$ \\
Transferrin $_{\mathrm{Tf}^{\mathrm{A}}}$ & & & & & \\
$\mathrm{Tf}^{\mathrm{AB}}$ & 0.05 & $\mathrm{NA}$ & 0.02 & 0.30 & $0.09 \pm 0.14$ \\
$\mathrm{Tf}^{\mathrm{B}+}$ & 0.90 & 1.00 & 0.87 & 0.55 & $0.83 \pm 0.20$ \\
\hline $\mathrm{NA}^{\mathrm{A}} \rightarrow \mathrm{Not}$ & 0.05 & $\mathrm{NA}$ & 0.11 & 0.15 & $0.08 \pm 0.07$ \\
\hline
\end{tabular}

\section{Hardy-Weinberg's exact test}

Results of the Fisher's exact test for HardyWeinberg's (HW) equilibrium across loci and populations, considering the heterozygote deficit as the alternative hypothesis, are shown on Table 6. No significant $(\mathrm{p}<0.05)$ multi-locus departures from HWE proportions were found for all the populations except population from Ogun that is significant $(\mathrm{p}<0.05)$. Only Tf locus showed very high significant $(\mathrm{p}<0.001)$ departures from HWE while all other loci showed no significant $(p<0.05)$ deviations from HWE. Also, the following markers were found to be in $\operatorname{HWE}(\mathrm{P} \leq$ $0.05)$ disequilibrium for a specific population (Table 7). For sample from Ogun state all the markers showed significant difference in the HWE disequilibrium, where the $\mathrm{P}$ value ranged from 0.00 to 0.01 , same trend was observed in the sample from Ondo with the $\mathrm{P}$ value ranging from 0.001 to 0.04 . In the sample from Osun state only Tf markers was significant in the HWE disequilibrium with $\mathrm{P}$ value of 0.00 . Also in the sample from Oyo state only CA maker was found not to be in HWE with $\mathrm{P}$ value of 0.00 . The two talbes (Table 6 and 7) revealed a very high significant $(\mathrm{P}<0.001)$ deviation from Hardy-Weinberg's equilibrium across all the populations for Transferrin locus, while all the populations were in HardyWeinberg's disequilibrium except population sample from Ogun state. The other two protein marker ( $\mathrm{Hb}$ and $\mathrm{CA}$ ) were found not to be significant $(\mathrm{P}<0.05)$ HardyWeinberg's disequilibrium, which suggest that those WAD populations were in HardyWeinberg's equilibrium for the two protein loci. All the populations were very highly significant $(\mathrm{P}<0.001)$ in Hardy-Weinberg's 


\section{Diversity of West African dwarf goat in southwestern Nigeria based on allozyme markers}

disequilibrium for Transfferin locus except for sample from Oyo state which is not significant $(\mathrm{P}<0.05)$. Li et al. (2002) reported a case of five Hardy-Weinberg's disequilibrium out of thirteen populations. Likewise all samples were significant $(\mathrm{P}<0.05)$ in Hardy-Weinberg's disequilibrium for Carbonic anhydraselocus except in population sample from Osun state. For Haemoglobin locus only sample from Ogun and Ondo state were significant $(\mathrm{P}<0.05)$ in HardyWeinberg's disequilibrium while population from Osun and Oyo were not significant $(\mathrm{P}<0.05)$.

Table 6: Hardy-Weinberg's exact test in the WAD goat populations

\begin{tabular}{|c|c|c|c|c|c|}
\hline Population & Pop. Size & P-val & Locus & P-val & S.E. \\
\hline Ogun & 40 & $0.012 * *$ & $\mathrm{Hb}$ & $1.000^{\mathrm{NS}}$ & 0.000 \\
\hline Ondo & 12 & $0.732^{\mathrm{NS}}$ & CA & $0.714^{\mathrm{NS}}$ & 0.013 \\
\hline Osun & 53 & $0.736^{\mathrm{NS}}$ & $\mathrm{Tf}$ & $0.000 * * *$ & 0.000 \\
\hline Oyо & 20 & $0.631^{\mathrm{NS}}$ & & & \\
\hline
\end{tabular}

Table 7: Hardy Weinberg's equilibrium for four populations of Nigerian WAD goat

\begin{tabular}{lllll}
\hline Locus/Population & Ogun & Ondo & Osun & Oyo \\
\hline $\mathrm{Hb}$ & $0.003^{* *}$ & $0.043^{*}$ & $0.467^{\mathrm{NS}}$ & $0.157^{\mathrm{NS}}$ \\
$\mathrm{CA}$ & $0.011^{*}$ & $0.010^{* *}$ & $0.732^{\mathrm{NS}}$ & $0.002^{* *}$ \\
$\mathrm{Tf}$ & $0.000^{* * *}$ & $0.001^{* * *}$ & $0.000^{* * *}$ & $0.655^{\mathrm{NS}}$ \\
\hline
\end{tabular}

$*=\mathrm{P}<0.05, * *=\mathrm{P}<0.01, * * *=\mathrm{P}<0.001 \quad \mathrm{Hb}---->>$ Haemoglobin, CA ---->Carbonic anhydrase,

Tf -.-->Transferrin

Effective sample size, expected and observed heterozygosity

The $\mathrm{H}_{\mathrm{O}}$ and $\mathrm{H}_{\mathrm{E}}$ for each locus and goat population are shown in Table 8 . It can be seen that $\mathrm{H}_{\mathrm{E}}$ was generally close to $\mathrm{H}_{\mathrm{O}}$ for all populations indicating no overall loss in heterozygosity. The value for $\mathrm{H}_{\mathrm{E}}$ and $\mathrm{H}_{\mathrm{o}}$ in each of the locus and population ranges from 0.19 for $\mathrm{Hb}$ locus in samples from Osun to 0.52 for Tf locus in sample from Ondoand 0.10 for CA locusin samples from Ondoto 1.00 for $\mathrm{Tf}$ locus in sample from Ondorespectively. The $\mathrm{H}_{\mathrm{E}}$ and $\mathrm{H}_{\mathrm{O}}$ values across all loci for different populations ranged from $0.39 \pm 0.18$ and $0.43 \pm 0.49$ for sample from Osun and sample from Ondo to $0.48 \pm 0.03$ and $0.62 \pm 0.30$ for sample from Ogun. WAD goat sample from Ogun showed a high degree of observed diversity (i.e.high heterozygosity) whereas WAD goat sample from Ondo were less diverse in terms of the analyzed loci.

\section{Gene diversity and Heterozygosity}

Aso In table 8 Gene diversity indicated by $\mathrm{H}_{\mathrm{E}}$ had a range of 0.19 for $\mathrm{Hb}$ in population from Osun to 0.52 for $\mathrm{Tf}$ in population from Ondo state while the $\mathrm{H}_{\mathrm{O}}$ ranged between 0.10 for CA in population from Ondo state and 0.90 for $\mathrm{Tf}$ in population from Ogun state. However, at Transfferin locusin all the populations and Carbonic anhydrase locus in two out of the four populations $\mathrm{H}_{\mathrm{O}}$ values were higher than their expected values indicating random mating which suggest that they are heterozygous in these populations and this was confirmed in the measure of deviation from HardyWeinberg's Equilibrium which was not significant $(\mathrm{P}<0.05)$ in sample from Ogun state while at the Haemoglobin locus, $\mathrm{H}_{\mathrm{O}}$ values were lower than the expected valuesexcept in sample from Ogun indicating departure from random mating which suggest that they are homozygous in 


\section{Awobajo, Osaiyuwu, Akinyemi, Salako and Odeniyi}

these populations, and also indicate ongoing selection or may be linked to other loci affecting morphological, productive or adaptive traits undergoing selection (Dixit et al., 2008; Bruno-de-Sousa et al., 2011) or result from mating between relatives and consequent genetic drift, similar to what has been observed in many other goat populations (Agha et al., 2008; Rout et al., 2008; Dixit et al., 2009). This could also be as a result of scoring bias (heterozygotes scored wrongly), selection against heterozygotes or inbreeding Barker et al. (2001).These result also implied that the sampled are more of homozygous in nature meaning that they have been subjected to certain level of inbreeding as a result of some form of selection within the various populations, (Dixit et al., 2008; Bruno-deSousa et al., 2011).

Table 8: Effective sample size (n) and expected and observed heterozygosity $\left(\mathrm{H}\right.$ and $\left.\mathrm{H}_{0}\right)$ at each locus for the populations and for the overall sample

\begin{tabular}{llllll}
\hline Locus & Ogun $\mathrm{n}=40$ & Ondo $\mathrm{n}=12$ & Osun $\mathrm{n}=53$ & Oyo $\mathrm{n}=20$ & Overall sample $\mathrm{n}=125$ \\
\hline $\mathrm{Hb} \quad \mathrm{H}_{\mathrm{E}}$ & 0.44 & 0.51 & 0.19 & 0.36 & 0.34 \\
$\mathrm{H}_{\mathrm{O}}$ & 0.65 & 0.20 & 0.17 & 0.25 & 0.34 \\
$\mathrm{CA} \mathrm{H} \mathrm{H}_{\mathrm{E}}$ & 0.50 & 0.40 & 0.49 & 0.51 & 0.49 \\
$\mathrm{H}_{\mathrm{O}}$ & 0.30 & 0.10 & 0.51 & 0.85 & 0.46 \\
$\mathrm{Tf} \quad \mathrm{H}_{\mathrm{E}}$ & 0.51 & 0.52 & 0.50 & 0.50 & 0.50 \\
$\mathrm{H}_{\mathrm{O}}$ & 0.90 & 1.00 & 0.87 & 0.55 & 0.84 \\
$\mathrm{All}$ Loci $\mathrm{H}_{\mathrm{E}}$ & $0.48 \pm 0.03$ & $0.47 \pm 0.07$ & $0.39 \pm 0.18$ & $0.46 \pm 0.09$ & $0.44 \pm 0.09$ \\
$\mathrm{H}_{\mathrm{O}}$ & $0.62 \pm 0.30$ & $0.43 \pm 0.49$ & $0.52 \pm 0.35$ & $0.55 \pm 0.30$ & $0.55 \pm 0.26$ \\
\hline
\end{tabular}

Hb --.-->Haemoglobin, CA -.-->Carbonic anhydrase, Tf --.->Transferrin

\section{Conclusion}

This study provides important information for the future conservation of WAD goat resources. Therefore it is a tool for breeding improvement because it will allow the preservation of the WAD goat populations and control of crossbreeding in future restocking programmes. The result of this study will be an addition to the baseline information about the WAD goat populations in the Southwestern Nigeria which will be useful for the improvement programmes of the breed and serve as reference for larger-scale diversity studies. Heterozygosities and allelic richness estimates for protein loci in this study indicate that WAD goat populations sampled are a reservoir of WAD goat diversity. FAO, 1988 reported that $\mathrm{Hb}^{\mathrm{A}}$ confer helminth resistance on the carriers such that the degree of helminth resistance is directly related to the number of dose of the A allele in the locus, the result of this study present the possibility for increasing helminth/disease resistance (for diseases that are associated with the hemoglobin genetic type) through selection against the $\mathrm{Hb}^{\mathrm{B}}$ allele. Protein loci analysis revealed additional information apart from the closeness between sample from Ogun and Oyo which is distinct genetic differentiation between sample from Ondo and that of Osun that can suggest that they are different from each other indicating greater room for improvement between the two populations through improvement programme. The genetic diversity of the WAD goat population was high as indicated by the mean number of alleles and expected heterozygosities observed for the populations. The genetic distance results revealed a closer relationship between WAD goat population from Ondo state and Osun state. 


\section{Diversity of West African dwarf goat in southwestern Nigeria based on allozyme markers}

\section{References}

Abdul-Aziz, M. 2010. Present status of the world goat populations and their productivity. Lohman Inf., 45: 42-52.

Adebambo, O. A., Williams, J. L., Blott, S. and Urquhart, B. 2004. Genetic relationship between native sheep breeds in Nigeria based on microsatellite DNA polymorphism. Anim. Genet. Resour. Inf., 34: 27-39.

Adedeji, T.A., Ozoje, M. O., Peters, S. O., Sanusi, A. O., Ojedapo, L. O. and Ige, A. O. 2011. Coat pigmentation and Wattle genes effect on some haematological characteristics of heat stressed and extensively reared West African Dwarf goats. World J. Life Sci. Med. Res., 3: 48-55.

Agha, S. H., Pilla, F., Galal, S., Shaat, I., D'Andrea, M., Reale, S., Abdelsalam, A. Z. and Li, M. H. 2008. Genetic diversity in Egyptian and Italian goat breeds measured with microsatellite polymorphism. $J$. Anim. Breed. Genet., 125(3): 194-200.

Akinyemi, M. O. and Salako, A. E. 2012. Genetic relationship among Nigerian indigenous sheep populations using blood protein polymorphism.Agricultural Science And Technology, Vol. 4, No 2, pp 107 112,2012

Arora, R., Bhatia, S., Mishra, B. P., Joshi, B. K., 2011. Population structurein Indian sheep ascertained using microsatellite information. Anim. Genet. 42, 242-250.

Arranz, J. J., Bayón, T. and San Primitivo, F. 1996.Genetic variation at five microsatelllite loci in four breeds of cattle.J. Agric. Sci. 127, 533-528.

Barker J. S. F, Moore, S. S., Hetzel, D. J. S., Evans, D., Tan, S. G. and Byrne, K. 1997. Genetic diversity of Asian water buffalo (Bubalusbubalis): microsatellite variation and a comparison with protein-coding loci. Animal Genetics 28: 103-115.

Barker, J. S. F., Tan, S. G., Moore, S.S., Mukherjee, T.K., Matheson, J.L. and Selvaraj, O.S., 2001. Genetic variation within and relationships among populations of Asian goats (Capra hircus). J. Anim. Breed. Genet. 118, 213-233.

Bourn, D., Wint, W., Blench, R. and Woolley, E. 1994. Nigerian livestock resources survey World Animal Review:78 1, 49-58.

Bruno-de-Sousa, C., Martinez, A. M., Ginja, C., Santos-Silva, F., Carolino, M. I., Delgado, J. V. and Gama, L. T. 2011. Genetic diversity and population structure in Portuguese goat breeds. Livestock Sci., 135: 131-139.

Buvanendra, V., Sooriyamoorthy, T., Ogunsusi, R. A. and Adu, I. F. 1981. Haemoglobin polymorphism and resistance to helminths in Red Sokoto goats.Trop. Anim. Health Prod., 13:217-21.

Camoglu, G. and Elmaci, C. 2005. Carbonic Anhydrase (Ca) and XProtein(X-p) Types in Turkish Sheep Breeds. Journal of Applied Animal Research, 28, 125-128.

Cavalli-Sforza, L. L., 1998. The DNA revolution in population genetics.Trends Genet, 14:60-65.

Christiansen, F. B., Frydenberg, O., Gyldenholm, A. O. and Simonsen, V. 1974. Genetics of Zoraces populations. VI. Further evidence based on age group samples of a heterozygote deficit EstIII polymorphism. Hereditas, 77: 225-236.

Dixit, S. P., Verma, N. K., Ahlawat, S. P. S., Aggarwal, R. A. K., Kumar, S., 


\section{Awobajo, Osaiyuwu, Akinyemi, Salako and Odeniyi}

Chander, R. and Singh, K. P. 2008. Molecular genetic characterization of Kutchi breed of goat.Curr. Sci., 95: 946-951.

Dixit, S. P., Verma, N. K., Aggarwal, R.A. K., Kumar, S., Chander, R., Vyas, M. K. and Singh, K. P. 2009. Genetic structure and differentiation of three Indian goat breeds.AsianAustralasian J. Anim. Sci., 22(9): 1234-1240.

Ebozoje, M. O. and Ngere, L. O. 1995. Genetic analysis of preweaning growth in West African Dwarf goats and their half-breds.Int. J. Anim. Sci., 10: 247-251.

FAO. 1988 Animal genetic resources conservation by management, data banks and Training. FAO Animalproduction and health paper 44/1. Rome, FAO, 1988.p.186.

Fitzhugh, H. A., Ehui, S. K., and LahlouKassi, A. 1992. Research strategies for development of animal agriculture.World Anim. Rev., 72: 9-19.

Ganai, N. A. and Yadav, B. R. 2001. Genetic variation within and among three Indian breeds of goat using heterologous microsatellite markers. Animal Biotechnology 12:121-136.

Groeneveld, L. F., Lenstra, J. A., Eding, H., Toro, M. A., Scherf, B., Pilling, D., Negrini, R., Finlay, E. K., Jianlin, H., Groeneveld, E., Weigend, S.and GLOBALDIV Consortium. 2010. Genetic diversity in farm animals - a review. Anim. Genet., 41(Suppl. 1): 6-31.

Hanotte, O. and Jianlin, H. 2005. Genetic characterization of livestock populations andits use in conservation decision-making in the role of biotechnologyVilla Gualino, Turin, Italy - 5-7 March, 2005.
Hoarau, G., Boon, E., Jongma, D. N, Ferber, S., Palsson, J., Van der Veer, H. W., Rijnsdorp, A. D., Stam, W. T. and Olsen, J. L. 2005. Low effective population size and evidence for inbreeding in an overexploited flatfish, plaice (Pleuronectes platessa L.). Proc. R. Soc. B, 272: 497-503.

Imumorin, I. G., Ologun, A. G. and Oyeyemi, M. O. 1999. Preliminary observations on effects of hemoglobin genotype and estimate of genetic distance at the $\mathrm{Hb}$ locus in West African Dwarf and Red Sokoto goats.Trop. J. Anim. Sci., 1: 1-9.

Jaayid, T. A. 2012. Serum Protein Polymorphism in Iraqi Local Goats using Polyacrylamide Gel Electrophoresis: Transferrin (BetaGlobulin) Polymorphism In: Proceedings of the First Asia Dairy Goat ConferenceApril 9 - 12, 2012 Corus Hotel Kuala Lumpur, Malaysiapublished by Universiti Putra Malaysia and The Food and Agricultural Organization Of The United Nations, pp 120-121.

Kemp, S. J. and Teale A. J. 1994. Randomly primed PCR amplification of pooled DNA reveals polymorphism in a ruminant repetitive DNA sequence which differentiates Bosindicus and $B$. taurus. Animal Genetics 25:83-88.

Kitalyi, A. J. 1998. Village chicken production systems in rural Africa. Household food security and gender issues. FAO Animal Production and Health Paper 142, p. 81.

Kotze, A., Swart, H., Grobler, P. and Nemaangani, A. 2004.A genetic profile of the Kalahari Red goat breed from South Africa. South African Journal of Animal Science. 
Diversity of West African dwarf goat in southwestern Nigeria based on allozyme markers

34(supplement I).

Laval, G., Iannuccelli, N., Legault, C., Milan, D., Groenen, M. A. M., Giuffra, E., Andersson, L., Nissen, P. H., Jorgensen, C. B., Beeckmann, P., Geldermann, H., Foulley, J. L., Chevalet, C. and Ollivier, L. 2000. Genetic diversity of eleven European pig breeds. Genet. Select. Evol., 32: 187-203.

Li M H, Zhao S H, Bian C, Wang H S, Wei H, Liu B, Yu M, Fan B, Chen S L, Zhu M. J, Li S J, Xiong T A and Li K 2002. Genetic relationships among twelve Chinese indigenous goat populations based on microsatellite analysis. Genetic Selection and Evolution.Volume 34 Article 6 $\begin{array}{lllllllll}R & e & t & r & i & e & v & e & d\end{array}$ http://www.ncbi.nlm.nih.gov/pubme $\mathrm{d} / 12473236$

Luikart G, Biju-Duval M-P, Ertugrul O, Zagdsuren $Y$, Maudet $C$ and Taberlet $P$ 1999. Power of 22 microsatellite markers in fluorescent multiplexes for parentage testing in goats (Capra hircus).Anim Genet 30:431-438.

Mahmoudi, B., Bayat, M., Sadeghi, R., Babayev, M. and Abdollahi, $H$. 2010. Genetic diversity among three goat populations assessed by microsatellite DNA markers in Iran. Global Vet., 4(2): 118-124.

Martínez, A. M., Acosta, J., Vega-Pla, J. L. and Delgado, J. V. 2006. Analysis of the genetic structure of the canary goat populations using microsatellites.Livestock Sci., 102: 140-145.

Mason I. L. 1984. "Goat”, in Mason, L.L., ed, Evolution of Domesticated Animals,

London, Longman: pp85-99.

Miller, Mark P. 1997. Tool for population genetic analyses (TFPGA) 1.3: A windosprogramme for the analysis of allozyme and molecular population genetic data. Computer software distributed by author.

Moruppa, S. M. 1985. A comparative study of Borno White and Red Sokoto (Maradi) goat breeds. University of Ibadan, Ibadan, Nigeria. (M.Sc. thesis)

Mourad, M., Gbanamou, G. and Balde, I. B., 2001. Performance of Djallonke sheep under an extensive system of production in Faranah, Guinea. Tropical Animal Health and Production 33(5): 413-422.

Muema, E. K., Wakhungu, J. W., Hanotte, O. and Jianlin, H. 2009. Genetic diversity and relationship of indigenous goats of sub- Saharan Africa using microsatellite DNA markers.Livestock Res. Rural Dev, 21(2), Article \#28. Retrieved October $7, \quad 2011, \quad$ f r o m http://www.lrrd.org/lrrd21/2/muem 21028. htm.

Mujibi, N. F. 2005 Genetic characterization of West African Dwarf (WAD) goats using microsatellite markers. MSc thesis submitted to the Department of Biochemistry and Biotechnology, Kenyatta University, Nairobi, Kenya.

Mwacharo, J. M., Otieno C. J., Okeyo A. M. and Aman R. A. 2002. Characterization of indigenous fattailed and fat-rumped hair sheep in Kenya: Diversity in blood proteins. Tropical Animal Health and Production, 34, 515-524.

Nei, M. 1972. Genetic distance between populations.Am. Naturalist, 106: 283-292.

Nei, M. 1973. Analysis of gene diversity in subdivided populations. Proc. Natl. 
Acad. Sci. U.S.A. 70, 3321-3323.

Nei, M., 1987. Genetic distance and molecular phylogeny.In "Population Geneticsand Fishery Management" (N. Ryman and F. Utter, Eds), pp. 193-223,University of Washington Press, Seattle.

Odubote, I. K. and Akinokun, J. O. 1992. Estimates of genetic parameters for economic traits in West African Dwarf goat.Nigerian J. Anim. Prod., 19: 114-19.

Odubote, I. K. 1994a. Characterization of the West African Dwarf goat for certain qualitative traits.Nigerian $J$. Anim. Prod., 2: 37-41.

Odubote, I. K. 1994b. Genetic analysis of the reproductive performance of West African Dwarf goats in the humid tropics. In: Small Ruminant Research and Development in Africa (eds. S.H.B. Lebbie and E. Kagwini). Proceedings Third Biennial Conference of African Small Ruminant Research Network, Kampala, Uganda. 5-9 December, 1994. pp. 33-36. International Livestock Research Institute, Nairobi, Kenya.

Okpeku, M., Peters, S. O., Ozoje, M. O., Adebambo, O.A., Agaviezor, B. O., ONeill, M. J. and Imumorin, I. G. 2011. Preliminary analysis of microsatellite-based genetic diversity of goats in southern Nigeria. Animal Genetic Resources, 2011, 49, 33-41. (C) Food and Agriculture Organization of the United Nations, 2011.

Ozoje, M. O. 1998. Coat colour genes in West African Dwarf sheep and goats: a theoretical appraisal. In Proc. Sixth World Congress of Genetics Applied to Livestock Production Vol. 26, pp. 54-57.

Rege, J. E. O. and Okeyo, A. M. 2006.
Improving our knowledge of tropical indigenous animal genetic resource.Version II, Module 2. In:Animal Genetic Training Resource Version 2, 2006. Ojango J.M. Malmfors, B. and Okeyo A.M. ( e d s ) I n t e r n a t i o n a 1 LivestockResearch Institute Nairobi, Kenya and Swedish University ofAgricultural Science, Uppsala, Sweden.

RIKEN 2006. Genetic Quality Monitoring by Biochemical Isozymes.RIKEN Bioresource Center. Experimental Animal Division RIKEN BioResource Center 6 September 2006.https://www.brc.riken.jp/ lab/animal/pdf/biochemical_pro.p df

Rout, P. K., Joshi, M. B., Mandal, A., Laloe, D., Singh, L. and Thangaraj, K. 2008. Microsatellite-based phylogeny of Indian domestic goats.BMC Genet., 9: 11.

Salako, A. E. 2004. Maturity rate of some morphometric traits in the West African Dwarf sheep of Nigeria.Trop. J. Anim. Sci., 7(1): $51-55$.

Salako, A. E., Ijadunola, T. O. and Agbesola, Y. O. 2007.Hemoglobin polymorphism in Nigerian indigenoussmall ruminant populations - preliminary investigation.African Journal of Biotechnology Vol. 6 (22),pp. 26362638.

Serrano, M., Calvo, J. H., Martínez, M., Marcos-Carcavilla, A., Cuevas, J., González, C., Jurado, J. J. and de Tejada, P. D. 2009. Microsatellite based genetic diversity and population structure of the endangered Spanish Guadarrama goat breed. BMC Genet., 29: 61.

Takezaki, N. and Nei, M. 1996. Genetic 
Diversity of West African dwarf goat in southwestern Nigeria based on allozyme markers

distances and reconstruction of phylogenetic trees from microsatellite DNA.Genetics, 144:389-399.

Visser C, Hefer, C. A., van Marle-Koste E. and Kotze, A.. 2004. Genetic variation of three commercial and three indigenous goat populations in South Africa.South African Journal of Animal Sciences 349 (Suppl.1):2427.

Wilson, R.T., 1991. Small ruminant production and the small ruminant genetic resource in tropical Africa.FAO Animal production and Health papers 88.FAO (Food and Agricultural Organization of the United Nations), Rome, Italy. Pp231.
Yakubu, A., Raji, A. O. and Omeje, J. N. 2010a. Genetic and phenotypic differentiation of qualitative traits in Nigerian indigenous goat and sheep populations.Asian Research Publishing Network (ARPN) Journal of Agricultural and Biological Science VOL. 5, NO. 2, PP 58-66.

Yakubu, A., Salako, A. E., Imumorin, I. G., Ige, A. O. and M. O. Akinyemi. 2010b. Discriminant analysis of morphometric differentiation in the West African Dwarf and Red Sokoto goats.South African Journal of Animal Science 2010, 40(4)

Yeh, F. C. and Yong, R. 1999. POPGENE version 1.31: Microsoft-based Freeware for Population Genetic Analysis. University of Alberta, Edmonton, Canada.

Received: $12^{\text {th }}$ May, 2018

Accepted: $31^{\text {st }}$ August, 2018 